\title{
Correction to: Viscosity Measurement by the "Oscillating Drop Method": The Case of Strongly Damped Oscillations
}

\author{
Georg Lohöfer ${ }^{1}[$
}

Published online: 1 June 2021

(c) The Author(s) 2021

\section{Correction to: International Journal of Thermophysics (2020) 41:30 https://doi.org/10.1007/s10765-020-2608-z}

The article "Viscosity Measurement by the "Oscillating Drop Method": The Case of Strongly Damped Oscillations', written by Georg Lohöfer, was originally published Online First without Open Access. After publication in volume 41, issue 3, page 1-13 the author decided to opt for Open Choice and to make the article Open Access publication. Therefore, the copyright of the article has been changed to (C) The Author(s) 2021 and the article is forthwith distributed under a Creative Commons Attribution 4.0 International License, which permits use, sharing, adaptation, distribution and reproduction in any medium or format, as long as you give appropriate credit to the original author(s) and the source, provide a link to the Creative Commons licence, and indicate if changes were made. The images or other third party material in this article are included in the article's Creative Commons licence, unless indicated otherwise in a credit line to the material. If material is not included in the article's Creative Commons licence and your intended use is not permitted by statutory regulation or exceeds the permitted use, you will need to obtain permission directly from the copyright holder. To view a copy of this licence, visit http://creat ivecommons.org/licenses/by/4.0.

The original article has been corrected.

Open Access This article is licensed under a Creative Commons Attribution 4.0 International License, which permits use, sharing, adaptation, distribution and reproduction in any medium or format, as long as you give appropriate credit to the original author(s) and the source, provide a link to the Creative Commons licence, and indicate if changes were made. The images or other third party material in this article are included in the article's Creative Commons licence, unless indicated otherwise in a credit line to the

The original article can be found online at https://doi.org/10.1007/s10765-020-2608-z.

Georg Lohöfer

Georg.Lohoefer@dlr.de

1 Institut Für Materialphysik Im Weltraum, Deutsches Zentrum Für Luft- Und Raumfahrt (DLR), 51170 Cologne, Germany 
material. If material is not included in the article's Creative Commons licence and your intended use is not permitted by statutory regulation or exceeds the permitted use, you will need to obtain permission directly from the copyright holder. To view a copy of this licence, visit http://creativecommons.org/licen ses/by/4.0/.

Publisher's Note Springer Nature remains neutral with regard to jurisdictional claims in published maps and institutional affiliations. 